\title{
“A DESCENT INTO THE MAELSTRÖM”: AESTHETICS OF SUBLIME AND EDGAR ALLEN POE
}

\author{
Arş. Gör. Tuğba AYAS ${ }^{1}$
}

\begin{abstract}
This paper aims to interpret Edgar Allen Poe's short story "A Descent into the Maelström" in terms of the virtues of the 18th century sublime aesthetic theoretically informed by the works of two prominent philosophers, namely Edmund Burke and Immanuel Kant. "A Descent into the Maelström" is a landscape story about a fisherman's escape from a deadly whirlpool called Moskoe-ström off the Norwegian coast in the North Sea. The aesthetics of sublime refers to a soul elevating experience of a piece of nature that is massive or mighty enough to cause human imagination to fail. Hence, it is possible to interpret this story in terms of the notion of sublime. The paper shall claim that Poe's short story exemplifies both a Kantian and Burkean understandings of the concept in a fashion that is peculiar to Poe's literary style. In the tale, the fisherman's and the narrator's experiences correspond to two kinds of sublime. Thus, in Poe's peculiar writing, Burkean sublime shall be traced back in the fisherman's experience of the whirlpool, whereas Kantian sublime in that of narrator's. Following these two philosophers and their descriptions of the sublime, the paper shall trace this notion in Poe's tale.
\end{abstract}

Key Words: Sublime, Burke, Kant, Poe, “A Descent into the Maelström”.

\footnotetext{
${ }^{1}$ Ph.D. Candidate, Faculty of Fine Arts, Ihsan Dogramaci Bilkent University; Research Assistant, Faculty of Fine Arts, Sakarya University, tugbaayas@ gmail.com.
} 


\title{
“MAELSTRÖM’E N Ş”: YÜCE ESTET Ğ VE EDGAR ALLEN POE
}

\begin{abstract}
ÖZET
Bu çalışma, ünlü yazar Edgar Allen Poe'nun “Maelström'e niş” başlıklı kısa hikayesini, Edmund Burke ve Immanuel Kant'ın eserleriyle ünlenen 18. yüzyıl yüce estetiğine başvurarak yorumlamayı amaçlar. "Maelström'e niş", bir balıkçının Kuzey Denizi'nin Norveç kıyılarında ortaya çıkan Moskoe-ström adlı ölümcül burgaçtan kurtuluş hikayesini anlatan bir tabiat öyküsüdür. Bu kısa öyküyü yüce kavramına dayanarak yorumlamak mümkündür. Zira bu estetik kavram bir insanın, boyutu ya da kuvveti ile insan ruhunu ve tahayyül yeteneğini geçici olarak olumsuz etkileyen bir doğa olayı ile karşılaştığı anı betimler. Bu çalışma Poe'nun, kendi yazı üslubuna özgün bir şekilde Kant'ın ve Burke'ün yüce anlayışlarını örneklediğini iddia edecektir. Hikayenin iki kahramanı olan balıkçı ve balıkçının hikayesini dinleyen anlatıcının yaşadıkları, iki tür yüce estetiğine karşılık gelir. Poe'nun eşsiz yazı stilinde, yaşlı balıkçının burgaçla imtihanında Burke’ün yüce teorisinin izlerine rastlarken, hikayeyi bize aktaran kişinin yaşadıkları Kantçı yüce anlayışını hatırlatır. $\mathrm{Bu}$ çalışma adı geçen iki filozofun yüce teorilerini takip ederek Poe'nun hikayesine bu kavramın izini sürecektir.
\end{abstract}

Anahtar Kelimeler: Yüce estetiği, Burke, Kant, Poe, "Maelström’e niş”. 


\section{Introduction}

Edgar Allen Poe is one of the most influential literary figures of the 19th century American Literature. Known to invent the genre of detective stories, Poe is famous for his gothic horror style of writing, tales of mystery and macabre in particular. Dated back to 1841 , his short story "A Descent into the Maelström" is published in Graham's Magazine where he also used to be an editor (Bittner, 1962:164). The story is about a famous tidal whirlpool off the coast of Norway. It is a landscape story depicting the might of nature in its full pride through the anecdote of a fisherman who finds himself in the midst of a lethal whirlpool and miraculously survives it. The story is told by the fisherman who once subjected to a "six hours of deadly terror" that unnerved him and turned his "hair into jetty black to white". There is another actor in the story. This is "a frame narrator" who "serves as the filter for the reader's response to an intriguing character” (Egan, 1982:158).

The story begins with the narrator's descriptions of the peak point of the Mount Helseggen the Cloudy. At first the altitude and the gale make the narrator dizzy. After recovering the initial shock, the narrator finds himself a relatively safe space and surrenders to the view and the story that the mariner begins to tell.

About three years ago one day in July the mariner sails with his two brothers in order to fish as any other day. They are used to the Maelström and most of the time they successfully would navigate it. Yet, in the day of the horrific experience, a hurricane appears out of nowhere. In about half an hour, the waves start to plunder and suddenly wreck the ship. The younger brother who ties himself to a mast is taken away by the waves that tear away the masts. The fisherman together with his elder brother endures to the full might of the maelstrom till the elder brother decides to hold on to the ring-bolt that he holds. He abandons the ring-bolt to his brother because he feels pity for him. Just after this, the waves pull the ship into the bottom of the whirlpool and his elder brother is also lost in the waves.

In his desperate state of mind, the fisherman miraculously comes to his senses and observes the objects around him. In a quick observation of his surroundings, the fisherman sees that the cylindrical shaped objects sink more slowly. Then he takes the risk of his life and holds on to a water cask. After lashing himself to the cask, he detaches himself from the boat. Unlike his brother's poor judgment, this maneuver saves him from going down with the boat and saves his life in the end.

At first glance the tale does not seem different -at least in its form- than Poe's "The Rime of Ancient Mariner" in which basically a preliminary narrator 
encounters another narrator who is eager to tell a sublime story with divine references. Yet, "A Descent into the Maelström" deserves attention with its alluring elements such as the unique sense of sublime Poe applies. This literary piece is full of both vivid and thrilling depictions of an exuberant nature. In this sense, Poe's story can well be read as an aesthetic experience and, an aesthetic experience of this kind can very well be examined in terms of sublime. The history of sublime goes back as early as to the 1st century by Longinus. However, the notion has been popularized along with the discussions on aesthetics of the 18th century. The notion is usually attributed to any kind of greatness in nature that overwhelms any physical, metaphysical, intellectual or moral limits. The vast history and various interpretations of the notion are outside the scope of this paper. Thus, for the present purposes it is convenient to focus solely on Poe and his acquaintance with the notion.

Poe is known to be familiar with Burke and his ideas on sublime. He is also known to write in an 'ironical tone' on German idealism and Kant in particular (Hansen and Pollin, 1995:88). As to the notion of sublime, it is noteworthy that more often than not, Poe's version of sublime is reported to diverge from both Burkean and Kantian versions. Kent Ljungquist maintains that in his landscape tales, Poe abandons the sublime in exchange for the picturesque, another essential notion of 19 th century aesthetics. He claims that this state is clear especially in A Descent which "marks triumph in the sublime mode but also the liquidation of its aesthetic possibilities" (1984:48). Therefore, Poe's divergence from the classical sublime is not surprising or accidental. He abandons both Burke's and, not surprisingly, Kant's version of the notion. It is mostly due to the fact that in classical sublime, an overwhelming experience of nature is transformed into either an appreciation of mental faculties or a theological reference. Yet, according to Jack Voller, Poe is fond of terrors with no redemption. Poe diverges from each of the mentioned theories of sublime because he does not domesticate the wild character of these terrors (1988: 27). In other words, Poe's sublime is ripped off the positive effects such as the reference to divinity of conventional sublime. In an attempt to read Poe's A Descent as a sublime experience, one should be aware of this fact and be cautious about the potential risk of a reduction or an over simplification of Poe's rendition of the notion. Therefore, this paper shall not try to address Poe's story as an apt example for either Kantian or Burkean sublime. Instead, it shall take recourse to these philosophers as to diversify the possible interpretations of the story. In terms of a possible sublime experience, a cautious correlation between Poe's tale and the Kantian and Burkean versions of sublime can be made.

Poe is known to use a multilayered story-telling technique and A Descent is one of his stories written in this way (Egan, 1982: 157). A Descent has two agents: 
the narrator who observes Maelström in a distance and; the fisherman who experienced it at first hand and presently tells his memoir. Poe presents two aesthetic experiences. First is the fisherman's past and authentic experience of the Maelström and; second is the experience of the young man's, in which he experiences the power of nature in front of him with the fisherman telling his story at the background. The position of the young man or the narrator subscribes to the conventions of Kantian sublime whereas that of the fisherman reminds Burke's definition of sublime. Hence, it can be said that the first level sublime is the one which the narrator experiences more recently, while the second level sublime is the one which the old man encountered three years ago.

\section{Kantian Sublime and the Narrator}

In Kant's aesthetics, laid bare by the philosopher in Critique of Judgment (1790), sublime corresponds to the mental state of the subject who confronts a grandiose nature. In this encounter, a natural grandeur affects and shocks the imagination faculty by its size or might. Kant defines this state as a mental movement. This mental movement is towards critical reason (faculty of cognition) provided that the piece of nature shocks us by its massive size, and it is towards the practical reason (desire) when it is the might of nature that overwhelms the faculty of imagination. These two different inclinations of the mind correspond to two different modes of sublime: the mathematically and dynamically.

According to Kantian theory of dynamically sublime, the imagination, which is the faculty of representation, is compelled to transcend its own limit during the attempt to represent what appears as the absolutely strong. What takes place in dynamically sublime is that "in the immeasurableness of nature and the incompetence of our faculty for adopting a standard proportionate to the aesthetic estimation of the magnitude of its realm, we found our own limitation" (1964:111). The absolute causality is implied by Idea of infinity in dynamically sublime. In such a state of distress of the imagination, there reveals the feeling of a supersensible faculty in us and by the help of this faculty we have the "courage to be able to measure ourselves against the seeming omnipotence of nature" (1964:111). Hence, even if the imagination fails in representing the might of nature in its entirety, its suffering is ceased by the help of reason. The sublime is marked mostly by this failure of imagination, but also by the sense of confronting the limit of sensibility, the shock and also the couple of pain and pleasure which for Kant is a negative pleasure. Hence, Kant describes a typical scene that evokes sublime as follows:

Bold, overhanging, and, as it were, threatening rocks, thunder-clouds piled up the vault of heaven, borne along with flashes and peals, volcanoes in all their violence 
of destruction, hurricanes leaving desolation in their track, the boundless ocean rising with rebellious force, the high waterfall of some mighty river, and the like, make our power of resistance of trifling moment in comparison with their might (1964:109).

There is one point that needs attention in Kant's rendition of the concept. In Kant's understanding, sublime feeling is evoked on the condition that the subject is in a safe distance from the power of nature which could well be lethal without the proper distance. Hence, in Kantian sublime subject is a spectator in the encounter with nature.

Back to Poe's story, the first level sublime that the narrator experiences, is similar to the Kantian sublime that corresponds to the mental state of the subject who confronts a grandiose nature. Before the old man begins to tell his tale, the narrator's anxious descriptions of the surroundings on the top of Helseggen Mountain remind the Kantian frame of sublime:

To the right and left, as far as the eye could reach, there lay outstretched, like ramparts of the world, lines of horridly black and beetling cliff, whose character of gloom was but the more forcibly illustrated by the surf which reared high up against it its white and ghastly crest, howling and shrieking for ever. Just opposite the promontory upon whose apex we were placed, and at a distance of some five or six miles out at sea, there was visible a small, bleak-looking island; or, more properly, its position was discernible through the wilderness of surge in which it was enveloped. About two miles nearer the land, arose another of smaller size, hideously craggy and barren, and encompassed at various intervals by a cluster of dark rocks (Poe, 2004: 106).

Then, in a mounting fear, the narrator observes the forming of the Maelström even if the distance is quite safe. As to him, the sight of ocean presents "a panorama more deplorably desolate no human imagination can conceive" (Poe, 2004: 106). He explicitly states that his imagination is compelled while estimating the depth of the whirlpool which is "incommensurably greater" than the assumed "forty fathoms" (Poe, 2004: 109). To the narrator, "the faintest conception either of the magnificence or of the horror of the scene-or of the wild bewildering sense of the novel which confounds the beholder" (Poe, 2004: 108) cannot be compared to any observation conveyed by some researchers. On the might of the whirlpool the narrator reports the following:

Looking down from this pinnacle upon the howling Phlegethon below, I could not help smiling at the simplicity with which the honest Jonas Ramus records, as a matter difficult of belief, the anecdotes of the whales and the bears; for it appeared to me, in fact, a self-evident thing, that the largest ship of the line in existence, coming 
within the influence of that deadly attraction, could resist it as little as a feather the hurricane, and must disappear bodily and at once (Poe, 2004: 109).

The safe position of the narrator does not prevent him from being terrified in this encounter with nature's sheer dynamical power. The endeavor to measure or conceive the might of the scene that circumscribes the whirlpool elevates the soul of the narrator. The failure of the faculty of imagination to present the scene rationally lays similar to the state that Kantian subject stands in sublime.

In Kantian sublime, as the spectator is saved by recourse to reason, s/he comes to realize the power of human mind. According to Kant, nature as a "power which is superior to great hindrances" (CJ §28) becomes an object of attraction when we realize that we are secure, that is, when it is felt that this might of nature has no 'dominion over us'. We confront our own limitation and a 'pre-eminence' over nature even it seems immeasurable. Thus, nature is called sublime because it "raises the imagination to a presentation of those cases in which the mind can make itself sensible of the appropriate sublimity of the sphere of its own being, even above the nature" (CJ §28). This is merely the moment of relief for the subject- the point after which everything turns to normal. Yet, for the narrator in Poe's story, the whole experience and the tension it entails increases drastically. This detail constructs the core of Poe's rendition of sublime: no redemption for the subject. This will be reissued on the section where Poe's sense of sublime is examined closely.

\section{Burkean Sublime and the Fisherman}

In contrast to the narrator's vicarious involvement, the fisherman is subjected to the Maelström. Poe's old man, as the subject of this exhilarating experience, witnesses to the full might of nature not only with his eyes or ears but with his whole body. In a cautious manner, we can interpret the awe and shock felt by the old man as an example to Burkean sublime.

In his 1757 treatise A Philosophical Enquiry into the Origin of Our Ideas of the Sublime and Beautiful Burke contends that

Whatever is fitted in any sort to excite the ideas of pain and danger, that is to say, whatever is in any sort terrible, or is conversant about terrible objects, or operates in a manner analogous to terror, is a source of the sublime; that is, it is productive of the strongest emotion which the mind is capable of feeling (1990: 36).

Similar to this definition, the fisherman in Poe's story describes his feelings pertaining to the bizarre experience as follows: "Never shall I forget the sensations of awe, horror and admiration with which I gazed about me" (Poe, 2004: 114). In the 
face of the horrendous scenery that Maelström presents, the imagination of the man suffers severely: "At first I was too much confused to observe anything accurately. The general burst of terrific grandeur was all that I beheld" (Poe, 2004: 115). The upheaval of emotions he is succumbed to results in a temporary apoplectic state of mind.

According to Burke, "When danger or pain press too nearly, they are incapable of giving any delight, and are simply terrible; but at certain distances, and with certain modifications, they may be, and they are, delightful, as we every day experience" (1990: 36). Following this, the life threatening ordeal of the fisherman does not seem to be a case of Burkean sublime at first. Obviously, the pain presses too nearly for the fisherman and his two brothers. For the two brothers, the incident is lethal and for the fisherman it is soul breaking since he loses two brothers. Yet, there are still some things to say for his experience. At the beginning, there is no doubt that the Maelström is 'incapable of giving any delight' and thus is 'simply terrible'. The way to the mariner's salvation is not smooth in any way. However, we see several signs of the restoration of his rational self throughout the story. Firstly, the wind's power to "blind, deafen and strangle" him stops at some point and he tells that it was the point in which he gained his self-possession back. When he observes the present circumstances his soul elevates in the encounter of the nature's sheer power. This time, he decides that it would not be such a bad thing to die in such an instant when he is surrounded by a clear manifestation of God's power. Following this uncanny relief, due to knowing that the end of his life is near; the mariner becomes indifferent to his fear and begins to observe the surroundings. "I must have been delirious --for I even sought amusement in speculating upon the relative velocities of their several descents toward the foam below" he says. This dizzy amusement leads the mariner's great awareness that the wreck of the ship goes down before a fir tree contrary to what he predicts.

After that, he starts to think and at that moment a feeling of curiosity invades his afflicted mind. He feels an urge to observe the whirl. For a moment he overwhelms his suffering by a full submission to rationality and thus, at some point he gets more thrilled not by "a new terror" but by "the dawn of a more exciting hope" (Poe, 2004: 116) - a hope that arises "partly from memory and partly from present observation". At this point of the ordeal, the fisherman applies to his memory and recalls that "the great variety of buoyant matter that strewed the coast of Lofoden, having been absorbed and then thrown forth by the Moskoe-ström" (Poe, 2004: 116). After remembering this, he also makes three rational observations as follows: 
The first was, that, as a general rule, the larger bodies were, the more rapid their descent- the second, that, between two masses of equal extent, the one spherical, and the other of any other shape, the superiority in speed of decent was with the sphere- the third, that, between two masses of equal size, the one cylindrical, and the other of any other shape, the cylinder was absorbed the more slowly (Poe, 2004: 120).

Through these observations, the fisherman speculates a way out of the whirlpool. In this sense or in just at that moment of this harrowing aesthetic experience, the mind of the fisherman gradually draws itself from the overwhelming feeling of the terror. Till this very moment, the whirlpool incident obviously represents a danger that "press(es) too nearly" and that offers no delight at all. Hence, in this sense Burke would not call the whirlpool sublime. However, with the reintroduction of rational powers, even a cunning escape from the whirlpool is possible. The life threatening whirlpool is turned into a phenomenon to observe and thus, something that can be escaped from. This is the very human condition on this total terror moment. The fisherman, in the very midst of the whirlpool, makes three observations that lead him to tie himself to a water cask and jump into the water in the end (Poe, 2004: 121).

Poe does not explicitly define any delight pertaining to the moment when the fisherman feels the hope for his rescue. Yet, if we follow Burke, the moment would present a partial delight since for Burke a delight corresponds to "the sensation which accompanies the removal of pain or danger". Similarly, the feeling of hope and the observations pave the way for his salvation.

Poe's landscape story can very well be counted as sublime. Nevertheless, other than these similarities, Poe's sublime diverges from both Kant's and Burke's renditions of the concept in other aspects. The next section will focus on these aspects that make the rendition of sublime unique to Poe's style.

\section{Poe's Unique Sense of Sublime}

As it is stated earlier, Poe's possible referral to the concept diverges from these two theories in several points. First of all, due to the fact that a life threatening terror that promises no delight would be 'simply terrible' for Burke, the mariner's experience of pure terror does not seem to be a proper example for this kind of sublime. Since apart from an ephemeral feeling of "hope" that we mentioned earlier, Poe does not explicitly refer to a feeling of pleasure in the ordeal of the mariner. Secondly, Poe's sublime does not necessarily and solely privilege the sense of sight as Burke and Kant did. The propagator or the fisherman lives through a horrible experience and its effects can still be observed in his body. Thus, the ordeal he 
survived breaks him both body and soul. In this sense, his experience of the Moskoe-ström is a whole body experience rather than a pure spectral one.

Another significant divergence is that throughout the story, Poe's attitude in terms of the status of religious references and that of the science appears as undecidable. Poe's story begins with Joseph Glanville saying:

The ways of God in Nature, as in Providence, are not as our ways; nor are the models that we frame any way commensurate to the vastness, profundity, and unsearchableness of His works, which have a depth in them greater than the well of Democritus (Poe, 2004; 105).

The ways of God mentioned above seems to be appreciated by the propagator when he tells with respect to the horrifying experience:

It may look like boasting-but what I tell you is truth-I began to reflect how magnificent a thing it was to die in such a manner, and how foolish it was in me to think of so paltry a consideration as my own individual life, in view of so wonderful a manifestation of God's power (Poe, 2004; 116).

In addition to this feeling of surrender to divine power, the propagator makes analogies to religious matters when he describes the surroundings. For instance, "a magnificent rainbow", that he tells is "like that narrow and tottering bridge which Mussulmen say is the only pathway between Time and Eternity". Egan interprets this passage as the doubt of the mariner about his salvation because "the rainbow has traditionally symbolized God's premise of mercy to mankind" (1982: 160). Therefore, the man's descriptions referring to God's power is an acceptance of his unavoidable death. Yet, in the following lines we discover that the feeling of despair peters out. Furthermore, divine reference does not repeat; neither the tale is concluded with a religious moral. Following Margaret J. Yonce, one can claim that Poe's tale is a quest for "spiritual transcendence" (1969: 26) rather than a set idea on religious matters. If we are to agree Yonce, it can be said that Poe takes recourse to wild terrors in order to legitimize a transcendence of subject. The peril is so close that the subject is involved both body and mind in it and this may supply the sufficient ground to interrogate one's life once and for all. At the point of transcendence Poe loses the link between classical renditions of the concept. The pursuit for transcendence is never achieved in Poe whereas for both Burke and Kant, sublime culminates in a kind of appreciation of nature's and thus, indirectly God's ways.

All the elements mentioned above indicates the unique feeling of terror Poe appeals. The terror that Poe's subjects experiences is more like a gothic terror that 
has no redemption. In this sense, as Jack Voller rightly puts, the "lack of redemptive possibility" neither Burke's nor Kant's sublime seems to apply to Poe's writings (1988:30). Yet, if we are to see these theories as a two-phase events, then it can be arguable that apart from the second part, that is the part where the subject is released from the terror, both Burke and Kant can be guide for understanding Poe's "A Descent into the Maelström".

In Burke's rendition of sublime, the terrified subject who is in pain can react to the fearful object and by preserving himself against it, can return to a state of equilibrium. This is managed by subject's detecting "some part of dignity and importance" in the things it contemplates. In Kant's notion of sublime, the subject's reason reminds the fact that besides the unimaginable might of nature human mind is capable of overwhelming any obstacle. Whatever the imagination goes through due to the size or the might of nature, reason reminds the principle of humanity and emphasize the freedom to act. In Kant, this is closely related to the moral principle. For sublime experience culminates in a kind of verification of the superiority of human faculties over nature. To sum up, both Burke and Kant defines sublime as an authentic experience for both the human mind and soul.

With respect to Poe's appeal of the concept, we should note again that the sublime feeling or the sublime terror is much more serious threat for the life of the subjects. They severely suffer physically besides the pain and unnerving emotions felt by the mind or the soul. In "A Descent into the Maelström", neither the old man nor the narrator achieves stress relief in the end of their unique experience of sublime. Poe's subjects goes to the edge of madness due to overwhelming terror. The awe described by the narrator is interrupted by the story of the mariner who has much more horrible things to tell. The last words are the words of the mariner. Thus, the mood of the narrator after of the story shrouds in mystery. Furthermore, there is no divine or human reference in the end of the turmoil of feelings. Poe does not give us a closure. Denis Pahl writes that this is mostly the case in Poe's gothic stories in which

the sublime thus never allows for a state of transcendence or redemption, as the encounter with the terrifying object-however it manifests itself, whether in nature, in art, or in another person-only results in undermining the unity of the self, in throwing the self into an irrecoverable state of instability and displacement (2009: 44).

The two subjects in the story exemplify Poe's attitude towards sublime. The mariner loses his psychological health whereas the frame narrator is shaken intellectualy in the encounter of such a phenomenon of Nature. 


\section{Conclusion}

Poe's unique touch of the 18th century notion of sublime is made clear by "A Descent into the Maelström". It diverges from the notion with more dramatic and thrilling descriptions of oceanic sublime. Furthermore, the subjects physically suffer from the might of nature. This paper tried to reread Poe's short story by taking recourse to Burke's and Kant's comprehensions of sublime as an aesthetic instance. Although, the particular renditions of the concept by each philosopher diverge especially in their approach to the meaning of this experience for the human subject, they can be applied as auxiliary theories in order to analyze Poe's gothic stories. "A Descent into the Maelström" in its specific structure, serves a model for Poe's attitude towards Nature in its most violent form. In this short story, once again Poe presents us what he understands from pure terror. With respect to sublime aesthetic, it can be stated that Poe is fond of terrors that cannot be eased and also of subjects that can never fully recover the effects of Nature's might. Even in the end of the story, the subjects are not freed from the fearful state of mind and so the soul breaking terror lingers on. This feature has made Poe a significant figure in Gothic writing. To sum up, recognizing the similarities and differences of Poe's version of sublime in comparison to the mainstream 18th century views on the subject is an enabling analysis for a better understanding of the great writer. 


\section{BIBLIOGRAPHY}

Bittner, William. Poe: A Biography. Boston: Little, Brown and Company, 1962.

Burke, Edmund. A Philosophical Enquiry into the Origin of the Ideas of the Sublime and Beautiful. Çev. Adam Philips. New York: Oxford University Press, 1990.

Egan, Jr., Kenneth V. "Descent into Ascent: Poe's Use of Perspective in "Descent into the Maelstrom", Studies in Short Fiction 19.2, 1982: 157-162.

Hansen, Thomas S. ve Pollin, Burton R. The German Face of Edgar Allen Poe: A Study of Literary References in His Works. Kolombia, Camden House Inc., 1995.

Kant, Immanuel. Critique of Judgment. Çev. James Creed Meredith. Oxford: Oxford University Press, 1964.

Ljungquist, Kent. The Grand and The Fair: Poe's Landscape Aesthetics and Pictorial Techniques. Ptomac, Maryland: Scripta Humanistica, 1984.

Pahl, Denis. "Sounding the Sublime: Poe, Burke and the (Non)sense of Language", Poe Studies/ Dark Romanticism, 42, 2009: 41-60.

Poe, Edgar Allan. The Collected Tales and Poems of Edgar Allan Poe. Herdfordshire: Wordsworth Editions Ltd, 2004. 26-9.

Yonce, Margaret J. The Spiritual Descent into the Maelström. Poe Newsletter 2.2, 1969:

Voller, Jack G. "The Power of Terror: Burke and Kant in the House of Usher", Poe Studies/

Dark

Romanticism,

21.2 ,

1988:

27-35 